\title{
The Dialogic Bond that Relieves: Encounter to Transcend Therapeutic Adherence*
}

Theme: Chronic care.

Contribution to the discipline: The dialogic bond is a contribution, from the theoretical, to the communicative interaction of nurse-patient care in the transition from hospital to the home and to the multidimensional phenomenon of therapeutic adherence. It reflects the aesthetic pattern of care and demonstrates how care during the transition of patients with coronary disease goes beyond nurse-patient communication. It permits contributing elements to the aesthetic pattern of care that lead to explaining how a patient manages to conduct mental processing that allow transforming the negative and transcend to a state of equilibrium.

\section{ABSTRACT}

Objective: This work sought to describe the meanings constructed by patients with coronary disease (PCD) the communication process used by nurses during the transition from the hospital (coronary care unit) to the home for therapeutic adherence. Method: The article corresponds to a qualitative study, which used an approach through grounded theory. The participants were 12 informants from the city of Medellin, Colombia. Data reliability was guaranteed. Results: Construction of a theoretical postulate: "Reconstructing the significance of treatment: from the indifference to reviving with a dialogic bond that relieves". The process faced by PCD, derived from the communication process, goes from "living in ignorance", "experiencing rupture with the treatment" to "reconstructing: finding sense" and, finally, "finding a state of harmony: new learnings". This last achievement is obtained when creating awareness in the "dialogic bond that relieves". Conclusions: The meaning granted by PCD to the communication process for therapeutic adherence is established when reaching transformation and expanding the conscience (creating awareness) in a "dialogic bond that relieves"; likewise, when this process is full of apathy and indifference, the sense of the treatment is lost.

\author{
KEYWORDS (SOURCE: DeCS) \\ Communication; bonding; adhesion; treatment adherence and compliance; nursing; coronary disease.
}

DOI: 10.5294/aqui.2019.19.2.5

To reference this article / Para citar este artículo / Para citar este artigo

Arango MC, Gómez AM. The Dialogic Bond that Relieves: Encounter to Transcend Therapeutic Adherence. Aquichan 2019; 19(2): e1925. DOI: 10.5294/aqui.2019.19.2.5

1 orcid.org/0000-0001-9015-430X. Universidad Nacional de Colombia. Colombia. macarangore@unal.edu.co

2 orcid.org/0000-0002-8641-1833. Universidad Nacional de Colombia.Colombia. amgomez@unal.edu.co

* Article derived from the research: Meanings of the nurse-patient communication process with patients with coronary disease for therapeutic adherence.
Received: 22/01/2019

Sent to peer review: $25 / 01 / 2019$

Accepted by peers: 21/03/2019

Approved: 25/04/2019 


\section{El vínculo dialógico que alivia: encuentro para transcender la adherencia terapéutica*}

\section{RESUMEN}

Objetivo: describir los significados que construye el paciente con enfermedad coronaria del proceso comunicativo utilizado por la enfermera en la transición del hospital (unidad de cuidados coronarios) al hogar, para la adherencia terapéutica. Método: el artículo corresponde a un estudio cualitativo, en el que se usó un abordaje a través de la teoría fundamentada. Los participantes fueron doce informantes de la ciudad de Medellín, Colombia. Se garantizó la confiabilidad de los datos. Resultados: la construcción de un postulado teórico: "Reconstruyendo el significado del tratamiento: de la indiferencia a renacer con un vínculo dialógico que alivia". El proceso que enfrentan los pacientes con enfermedad coronaria, derivado del proceso comunicativo, va desde "viviendo en el desconocimiento", "experimentando ruptura con el tratamiento" hasta "reconstruyendo: encontrando sentido" y, finalmente, "encontrando un estado de armonía: nuevos aprendizajes". Este último logro lo obtienen al crear conciencia en el "vínculo dialógico que alivia". Conclusiones: el significado que le otorgan los pacientes con enfermedad coronaria al proceso comunicativo para la adherencia terapéutica se establece al alcanzar transformación y expandir la conciencia (crear conciencia) en un "vínculo dialógico que alivia"; asimismo, cuando este proceso se encuentra colmado de apatía e indiferencia, se pierde el sentido del tratamiento.

PALABRAS CLAVE (FUENTE: DECS)

Comunicación; vínculo; adherencia; cumplimiento y adherencia al tratamiento; enfermería; enfermedad coronaria.

* Artículo derivado de la investigación: significados del proceso comunicativo enfermera-paciente con enfermedad coronaria para la adherencia terapéutica. 


\section{O vínculo dialógico que alivia: encontro para transcender a adesão terapêutica*}

\section{RESUMO}

Objetivo: descrever os significados que o paciente com doença coronária constrói do processo comunicativo utilizado pela enfermeira na transição do hospital (unidade de cuidados coronários) ao lar para a adesão terapêutica. Método: este artigo corresponde a um estudo qualitativo, no qual foi utilizada uma abordagem por meio da teoria fundamentada. Participaram 12 informantes da cidade de Medellín, Colômbia. Garantiu-se a confiabilidade dos dados. Resultados: a construção de uma premissa teórica "Reconstruindo 0 significado do tratamento: da indiferença a renascer com um vínculo dialógico que alivia". 0 processo que os pacientes com doença coronária enfrentam, derivado do processo comunicativo, vai desde "vivendo no desconhecimento", "experimentando ruptura com 0 tratamento", até "reconstruindo: encontrando sentido" e, finalmente, "encontrando um estado de harmonia: novas aprendizagens". Este último é atingido ao criar consciência sobre o "vínculo dialógico que alivia". Conclusões: 0 significado que os pacientes com doença coronária outorgam ao processo comunicativo para a adesão terapêutica é estabelecido ao alcançar transformação da consciência e sua expansão (conscientizar) em um "vínculo dialógico que alivia"; além disso, quando esse processo se encontra permeado de apatia e indiferença, perde-se 0 sentido do tratamento.

PALAVRAS-CHAVE (FONTE: DeCS)

Comunicaçao; vínculo; aderência; cooperação e adesão ao tratemento; enfermagem; doença das coronárias.

* Artigo derivado da pesquisa: significados do processo comunicativo enfermeira-paciente com doença coronária para a adesão terapêutica. 


\section{Introduction}

Currently, cardiovascular disease represents one of the principal causes of morbidity and mortality in Colombia. The 2014 report by the World Health Organization (WHO) determined how this disease produces the highest number of deaths globally (1). It has been determined that non-adherence to pharmacological or non-pharmacological treatment is associated to non-control of the disease, which implies increased complications and, likewise, according to Iuga and McGuire (2), costs of hospital care. Conthe et al., (3) determined that $50 \%$ of patients with chronic diseases present lack of therapeutic adherence.

Additionally, literature has reported that variables, like quality in communication, trust, and empathy with the patient are factors that permit improving adherence and are highly correlated with therapeutic adhesion $(4,5)$; communication is one of the fundamental pillars to achieve this, given that authors, like Linn et al., (6) and Zullig et al., (7) have determined that communication is an important resource to support adherence to medications in patients with cardiovascular disease. Likewise, the meta-analysis by Zolnierek and Dimatteo (8) with 127 studies revealed the existence of a relationship between the way of communicating with patients and adherence, and indicated that the probabilities of adhesion by patients are 2.16 times higher if effective communication exists.

The studies cited refer to the relationship between the manner of communicating with the patient and therapeutic adherence, but it is necessary to explore the meanings the patient grants to the communication process as fundamental factor in nursing care. According to Shannon and Weaver (9), all communication produces behaviors, besides producing meanings. For this reason, the present research sought to describe the meaning granted by patients with coronary disease (PCD) to the communication process used by nurses during the transition from the hospital to the home for therapeutic adherence.

\section{Methodology}

This study had a qualitative approach and used as method the grounded theory (GT), guided through the Corbin and Strauss guidelines (10), which permits explaining social processes and meanings from the point of view of those constructing them. It uses a systematic and dynamic non-sequential design to gen- erate categories, which permits data to come and go, to prove that the interpretation made is congruent with the expressions of the participants, through constant comparison (11). Development of this methodology focuses on symbolic interactionism, about which Blumer proposes how patients act from the meanings things have for them (communication), and do not merely respond to stimuli (12).

To gather the information, a founding aspect of GT was considered: The quality and depth of the data collected (1l). Upon this, the study opted for the in-depth interview, a method that permits obtaining a wealth of information, of holistic nature and contextualized, through the words of the interviewee (the PCDs). That method favored the transmission of non-superficial information and permitted analyzing the meanings (13).

It is worth nothing that each interview was transcribed and coded before continuing with the second interview to comply with the criteria established by the GT: Data collection must be followed immediately by the analysis so that it becomes a guide for the next data collection (11).

The study had 12 participants considered PCD, who were in the transition process (discharge) from the coronary care unit (CCU) to the home, in an institution of Medellin, and the number of participants was determined by the theoretical sampling, a point where properties, dimensions, or new relationships no longer emerge during the analysis process (11). Of these, five were women and seven were men, ranging in age between 58 and 78 years; time of the disease ranges between five months and 12 years, which is equivalent to the same time required of treatment of chronic use, both pharmacological and non-pharmacological.

To maintain method rigor, the study kept in mind the criteria by Chiovitti and Piran (14) for qualitative research, with the GT approach: Credibility (the participants' own language was used in all coding levels and the data were validated with the participants), auditability (data were examined among different levels of codes existing in the literature to, from them, consolidate conclusions equal or similar to those of the original researcher), and transferability (the work described the relationship of the categories emerging with respect to the literature). Each criterion was key to maintain the work's internal coherence.

It is emphasized that to conduct the research, it was endorsed by the Ethics Committee at Universidad Nacional de Colombia 
and approved by the health institution where the interviews took place. The ethical principles of beneficence and non-maleficence, truthfulness and fidelity were considered, as well as the right to confidentiality and privacy, the right to self-determination and to being informed about the nature of the research, the potential benefits, and inconveniences the study can have to the participants. To comply with the aforementioned, an informed consent was elaborated, detailing the fundamental aspects, like potential benefits, the right to resign, management of data, and the promise of reliability and relevance of the study in nursing care. This permitted participants to freely decide whether to participate in the study, as well as to resign at any moment, if they so desired.

The data analysis used open coding (to analyze line by line), axial coding (to relate codes), and selective coding (to integrate concepts around the central category), bearing in mind - as base - two fundamental elements: The constant comparison and the "theoretical sensitivity" (15); this process permitted describing in detail three constructs: One related with the difficulties experienced with communication on discharge (passage from the CCU to the home) "Perceiving difficulties in the trajectory of the treatment from communication for care", and two related with satisfactory communication: "Establishing dialogic bonds that heal" and "Originating resonant: Transform communication".

Finally, from a higher level of abstraction, an analytic integration was performed through diagrams and an abstract representation of the data was obtained (10), which permitted proposing and describing the medullar category denominated "Reconstructing the meaning of treatment: From the indifference to reviving with a dialogic bond that relieves". From this postulate, "the dialogic bond that relieves" is highlighted, a medullar structure upon which the whole process revolves to transcend to the construction of creating awareness regarding the therapeutic adherence, and as a way of finding a state of wellbeing.

Thus, the categories described ahead are constructed from their properties and dimensions.

\section{Difficulties of the treatment from communication for care}

During the transition process (discharge), patients can experience communicative encounters with the nurse, considered asynchronous: They feel indifferent, ignored and with lack of in- formation for self-care, which produces an alteration in the process of therapeutic adherence that leads them to lose sense of the treatment.

...during discharge, they treat you coldly, indolently, what we came to do .... and I believe that sometimes not even like that, they don't even look at you [PCD: 12.12.19].

...they give you papers for you to claim, and nobody explains anything [PCD: 01.01.31].

Given the importance of the communication process during the transition from the hospital to the home, a moment when information is transmitted and the patient is educated for self-care and management of the treatment of chronic use, when this process becomes negative for the patient, it generates a "dealing with communication barriers for care", and patients report feeling "indifferent to the other" (nurse) or "immersed in ignorance and losing credibility in the treatment".

...you are there waiting, you are not explained anything, but no, they (nurses) don't even look at you... that feels bad because you go home the same way as you arrived [PCD: 07.07.17].

The use of technical language associated to apathy is another limitation in a communication process that affects learning for self-care, given that it generates feelings of anger and lack of motivation.

...you are hard pressed to understand what they tell you [...] you see they talk that way so that you cannot understand them, I didn't ask them anymore, and sure, what are you going to ask them if they are so grim as they are rude, that gives you so many things, like anger, and it discourages [PCD: 12.12.38].

Messages transmitted in confusing or incomprehensible manner are omitted and forgotten, and do not generate any importance; due to this, patients also resort to other learning strategies that do not cover their needs and can lead them to making mistakes. With all these experiences, fear is consolidated and this emotion becomes an impediment to establishing and mobilizing strategies of self-care.

In those encounters, the word $N O$ tends to be reactive and taxing, and generates conflicts in the communicative interaction of care. This word impedes entering into harmony with the other 
(patient), which is why patients report having had feelings of frustration and lack of support:

... the answers one receives is everything "NO"..., for everything, you ask them and them ... and that also fill you up with anger, and you start to fight with them (nurses) and you don't reach any understanding or find support, and learn something, much less [PCD: 02.02.28].

Lacking information to give continuity to the treatment of chronic use at home makes patients more vulnerable and does not let them take on positive actions; on the contrary, patients experience a variety of critical conditions and adverse feelings, like uncertainty, suffering, and frustration with the treatment.

...imagine that my husband died because, of all the hospitals where we went, nobody explained to us how we had to take care of him, what medications to give him [PCD: 01.01.45].

Losing the sense of the treatment is founded in that, at cognitive and psycho-emotional levels, they experience fear and disbelief, consequential of the absence of fruitful communicative encounters, where mutual understanding can take place and they can live shared experiences that generate awareness.

...for several reasons, I did not go back to the controls, I never took anything again; one of them, and of which I just realize, is that none of the people who treated me, not the physician or the nurse, created in me the conscience to take the medications [PCD: 04.04.22].

Lack of self-care and adherence are associated with the questions that arise during the very self-care, which are not solved, given that patients have not been accompanied.

In the search for alternatives due to the limitations they experience, patients and their relatives are subjected to obtaining information that, quite often, influences or leads them to remain in a state of confusion, which impacts upon the patient's emotional and physical dimensions.

...I get very concerned about my mom [daughter of the PCD], I want to know it all, and more so when they don't tell her so many things that are important to take care of her and for them [PCD] to heed. So, since you have information more easily at hand because in the computer you find everything, but since you don't understand, you start to read and get all influenced [PCD: 01.01.18].

\section{Establishing dialogic bonds that relieve}

Communicative encounters mediated by healing words and cozy contexts permit the formation of affective bonds represented in rapport and communicative harmony between the patient and nurse.

The dimensions that characterize the dialogic bond depend on: 1) The coupling or the way to synchronize the communication process for it to respond to the needs; 2) The quality of the messages or the clarity in the language used to transmit messages that meet the expectations of each patient; 3) The duration versus the quality of the encounter, given that patients do not demand prolonged times in the discharge and, on the contrary, seek spaces and settings to establish a communication process ladened with human quality and learnings; and 4) The human quality, represented in the words issued, in the non-verbal communication (treatment and tone of voice), and in the messages that transmit peacefulness to the patients and make communicative encounters soothing.

In a friendly communication process, empathy emerges as an integrating mechanism for the maintenance of the whole process; it is constructed as of the warmth with which the encounter begins and is nourished in how messages are transmitted: Clarity, fondness and humanity. It is a crucial factor to have encounters that permit overcoming those negative feelings and difficulties derived from lack of knowledge.

...if empathy exists along with that humanity and warmth to teach you how to handle yourself, how to go out and how to care for yourself; that make you fond of the treatment, [...] I learned to endure it, I calmed so many fears, it is that she [the nurse] like that with me, we understood each other well, and I achieved many things for my care, both with my treatment as with everything [PCD: 04.04.14].

In these settings, they discover each other again and new meanings of the treatment are found, like:

... an inseparable life companion [PCD: 06.06.07], a way of finding quality of life. [...] [PCD: 03.03.18] and understanding how ... the information was necessary for me to now be well and not quit the treatment [PCD: 04.04.25].

Patients argue that communication is supported on reciprocity and on the transmission of comprehensible messages; they 
find in it a sense for life during the trajectory of the treatment; it also becomes a therapy to achieve relief, tranquility, and credibility, given the power and force these messages have.

...communication kind of reaches this sick heart and heals you; it is funny, but that's the way it is [PCD: 06.06.11].

With communication that relieves, one learns to endure the treatment through awareness, which permits maintaining a balance in the health status.

\section{Originating resonant communication: Transforms}

Resonant communication is described as a therapeutic element that permits "transforming and creating awareness (transcending)"; it emerges due to interconnections, like the "dialogic bond that relieves", when patients maintain active a reflexive function as reasoning strategy and retrospective and prospective comparison of the past, present and future regarding the treatment, throughout their lives.

For some of the participants, the information transmitted "stays working in your head and creates awareness of doing everything better to find wellbeing" [PCD: 08.08.18]. These reasoning permits them to scale in the process until finding a satisfactory trajectory of the treatment.

For PCD, words of resonant communication cause in them an experience of "feeling cared", given the affective component immerse in them. This way, they form positive bonds with the treatment and manage to see it "with love or... as a small magnet that cannot be detached” [PCD: 09.09.24].

Resonant communication has a regulating component that permits awakening positive feelings to construct motivations that stimulates in them the desire to struggle and find states of wellbeing. Figure 1 illustrates the process of resonant communication.

Figure 1. Resonant communication

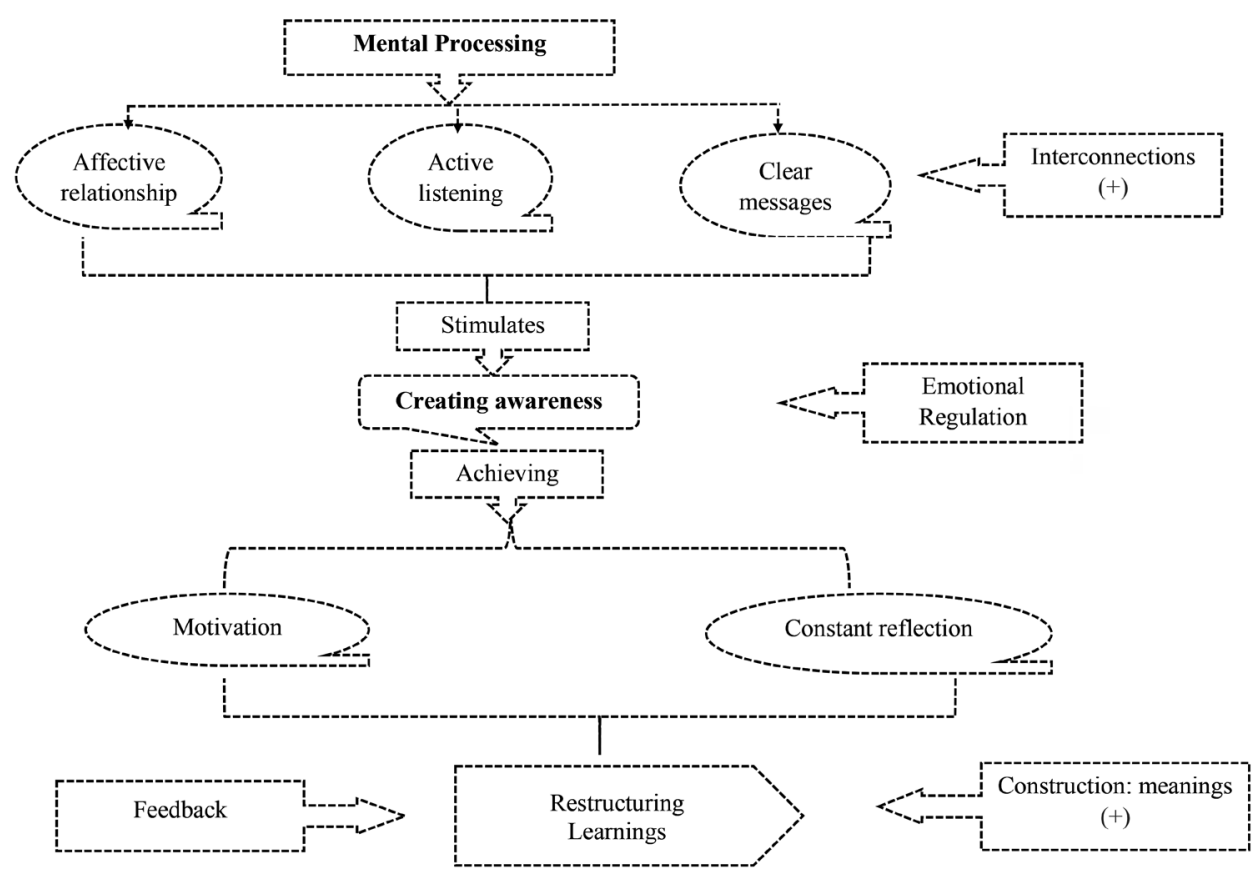

Source: Recovered from Arango MC (16), 122. 
In this process, when the relationship is human and affective, alliances are created of mutual learnings:

...the way they reach out to you, how they explain it, it is for you to find a true meaning to take so much drugs to heal and not quit, how can one find sense in something that one does not know, does not understand, well I don't know [PCD: 03.03.20].

In this new communication process, patients recognize the importance of learning to carry out the treatment to avoid relapse, not as an imposition established by another, but to reach stability, give that "one [a PCD] becomes aware of doing everything better for one's wellbeing, not because of scolding or fear, but to be well" [PCD: 08.08.18].

\section{Theoretical approach}

\section{Reconstructing the meaning of the treatment: From the indifference to reviving with a dialogic bond that relieves}

An extensive analysis of the data permitted understanding how the therapeutic adherence acquires meaning within the context of the communicative encounter; the central category is the result of the reduction of the information collected during the interviews, through an inductive process and of constant comparison of the data (11). It describes how the process starts when PCD confront a disorder, a product of communication barriers for care during the transition (discharge), upon perceiving indifference. Said indifference immerses them into a state of lack of knowledge, which makes them lose sense of the treatment and get sick again. Patients in condition of continuous vulnerability, impotence, and confusion must assume a therapeutic process that requires clear and motivating education.

If the communication process is characterized by empathy, mutual growth, harmony (understanding) and words that care, the denominated "dialogic bond that relieves" is formed, which emerges from the need to acquire significant learning for one's own care. These words permit enhancing the care interaction, as well as sharing ideas and experiences in a mutual process. This form of communication for care is resonant in the patient, that is, it transforms meanings and negative emotions and modifies the course of the treatment, given it overcomes the need for information and the uncertainty, product of the lack of knowledge.
In the "dialogic bond that relieves", ties and creative and empathic interconnections of care are formed that offer satisfaction and permit the rebirth and the emotional regulation that provide security to the patient to continue. In this encounter, patients are perceived as active agents of their care, which is why their vision of the treatment changes and are transformed into protectors to maintain an equilibrium with the disease.

\section{Discussion}

This study arrives at the concept of the "dialogic bond that relieves", which permits representing and nourishing the aesthetic pattern of care, besides feeding back the elements of care within the context of the transition and the therapeutic adherence, recognizing that it is about a multidimensional phenomenon and with high influence as of the communication process.

From the etymological roots of Latin, the word communication comes from comunicare, which means 'to share something, put in common', or the means that permits a union and bond, and from vinculum, which means 'union or tie of one person or thing with another' (17). Thus, when joining both concepts, it can be appreciated how communication (verbal and non-verbal) is a key process through which two people are linked to put in common thoughts, needs, knowledge, and to establish a relationship of nurse-patient help.

Upon analyzing the theories of bonds, it was found that these have been studied from different areas of knowledge, and that it is a process that is part of the evolution (survival), development (finding care, learning, and emotional health), and relationship of the human being (finding meaning to experiences).

From the theory of attachment, Bowlby (18) has determined how the bond maintains its conservation from the proximity with another individual trained to help face the world; it is through the bond that human beings find relief, consolation, and care. This concept is related with that described in the "dialogic bond that relieves", by being associated with the rapport and communicative harmony that characterize it, to help relieve the anguish product of not knowing, and to experiencing a climate of affection and trust, to transcend to creating awareness regarding the treatment.

The classic concept of bond by Pichon-Rivière gets closer to the phenomenon of the "dialogic bond that relieves", a complex 
spiral structure involving the transmitter, receptor, coding and decoding; in each turn there is interaction to gain feedback and solve contradictions between the parts (19). Likewise, the "dialogic bond that relieves" is a dyadic process, readjusted and coupled to the needs of patients, where knowledge is mutually fed-back through words that relieve and care, and a communicative synchrony is created that permits constructing motivations that vanish the anguish and reach a rebirth connected to the treatment.

Communicative synchrony (patient-nurse) is an evident element in the bond, which permits patients and nurses to develop a relationship of "sensing tacit subjective meanings" from experiences and situations that expand conscience and to construct meanings (20).

One way to validate the expansion of conscience (creating awareness) in the dialogic bond against the condition of coronary disease is through the health theory as expansion of conscience (21), which affirms how the expansion of conscience is an innate trend of human beings. Although some experiences and processes precipitate it, in this case, the "dialogic bond that relieves" leads to faster transformations, and the mutual nurse-patient association permits reflecting on the evolutionary pattern (therapeutic adherence). Each knowledge they acquire in the process leads to awakening and to transforming the conscience at a higher level.

Each process lived in the "dialogic bond that relieves" is a representation of the dialogue experienced, which is why it became the medullar unit, the fundamental pillar of care, being the search form for common understanding. It is the environment that permits knowing each other reciprocally and offer unique care; in it, one speaks to and listens to the other to understand the fear and uncertainty they face due to lack of knowledge (22). Acosta and Garcés (23) have defined how the knowledge dialogue permits creating encounters to weave bonds, as well as to recognize the other (patient).

Resonance was another component within the communication that relieves. It showed the new mental processing patients manage to carry out when understanding exists in the interaction of care. According to Meleis (20), resonance describes the direction of change from the lowest wave patterns to the highest. In the dialogic bond that relieves, it was possible to scale from an indifference (lowest level) to a revival accompanied by the treatment (highest level).
Ramírez et al., (24) state that the bond is a phenomenon that facilitates improving the attitude regarding the treatment and achieving its loyal adherence, given that participative processes are established that permit patients to carry out a positive co-construction of the meaning of the treatment. For this reason, the PCD, when constructing a "dialogic bond that relieves" with the nurse, manages to feel projected and finds a meaning to the experience.

Furthermore, the study by Flórez and Hernández (25) reported that for $32.6 \%$ of patients, treatment was complex to understand, due to confusing explanations, while $36.8 \%$ ignored how to treat the disease. The result is congruent with that reported in the study in which patients manifest confusing explanations, or the lack of these, and ignore how to continue the trajectory of the treatment, which leads them to feeling indifferent for the other (nurse) and to giving up the treatment.

According to the systemic cognitive theory of communication (26), the way information enters the system (brain) is fundamenta. Given that, according to this, it is conserved (memory), recovered and used (knowledge) to produce new changes (creating awareness); thus, human beings take only the information that is susceptible to being grouped in the conscience, to generate a mental representation. This agrees with the results and explains why when for patients the messages were confusing and incomprehensible, these were forgotten and had no important meaning for self-care, while when they found sense, their conscience expanded, and that generated in them a sense of wellbeing, which permits achieving therapeutic adherence.

From the perspective of interpersonal relationships in nursing, Peplau (27) states that clarity in messages ensures a useful communication process, an evident element in the "dialogic bond that relieves", for patients to reach significant learning.

The concept of transactions described by King (28) was also related with the "dialogic bond that relieves", given that two individuals identify with each other significantly and mutually (nursepatient), and interact to reach agreements and establish shared therapeutic goals (mutual objectives), understood, applied, and adapted to daily life.

Multiple studies, like those by Deley et al., (29), Arnow and Steidtmann (30), Vélez (31), Durig, Rous and Rousset (32), have 
demonstrated how making shared decisions, the bonds, association models during care, and the positive therapeutic alliances permit forming contexts where patients manage to feel secure to achieve therapeutic success and shape their disease through the medication. This statement explains why when patients find a dialogic bond that relieves, they construct a mutual association that lets them learn to endure the disease, because they perceive treatment with love and as a way of maintaining the quality of life.

According to the systematic review by Cófreces et al., (33), high levels of adherence are associated with communication models where negotiation processes, agreements, and comprehension are constructed. These elements, implicit in the dialogic bond that relieves, led to scaling higher stages, like the therapeutic adherence.

The growth reached in the "dialogic bond that relieves" is also fruit of the feedback, a process that makes the other a participant (patient) of the communicative interaction and guarantees comprehension of the messages. For Weinstein (34), feedback is a way of giving structure to a relationship and of finding support; this element permits PCD to give sense and meaning to the treatment.

To end, the systematic review by Zill et al., (35) shows the existence of multiple psychometric instruments that measure communication during health care, but not with respect to the communication for nurse-patient care during the transition from the hospital to the home for therapeutic adherence. This study is the description of a theoretical first level of the phenomenon, which generates some elements that can be retaken during its construction.

Upon studying the bonds described in other areas of knowledge, it may be stated that the bond defined in this study results authentic or genuine because its construction occurs through words and dialogues that inspire and transfer care, and inspire the search for a meaning of the treatment of chronic use to adapt it and maintain it in daily life.

\section{Conclusions}

The detailed analysis and the interrelation between each of the categories permitted to conclude that, according to the communicative experience faced by patients during the transition from the hospital to the home for therapeutic adherence, is defined a path loaded with failure or success with the treatment. Thus, communication barriers in care lead to losing sense of the treatment and make patients invisible during the transition. Experiencing a satisfactory communicative interaction modifies the patients' vision with respect to their treatment, it permits their regulating their negative emotions, as well as finding a reason to continue and reassign new meanings to the treatment. Due to this, it acquires the meaning of "reviving with a dialogic bond that relieves".

The process that describes the actions/interactions of "reviving with a dialogic bond that relieves" is discovering that "words care (transform)". It is characterized by being individual and dynamic, and it permits scaling until finding a new sense to the treatment. However, not all patients manage to reach the ideal, some remain "trapped" in the webs of communication barriers, which keeps them from granting sense to the treatment and projecting it as a life companion.

The meaning constructed by PCD from the qualitative permits understanding that the communicative processes they experience are determinant and constitute the central axis to construct motivational schemes and give a positive meaning to the treatment.

Conflict of interest: None declared. 


\section{References}

1. Organización Mundial de la Salud. Informe sobre la situación mundial de las enfermedades no transmisibles [Internet]. 2014. Available in: https://apps.who.int/iris/bitstream/handle/10665/149296/WHO_NMH_NVI_15.1_spa.pdf;jsessioni d=D9F6D2E5B400BC65290ADCBB955D2BE3?sequence $=1$

2. Iuga AO, McGuire MJ. Adherence and health care costs. Risk Manag Health Policy. 2014 Feb. 20; 7:35-44. DOI: 10.2147/ RMHP.S19801

3. Conthe P et al. Adherencia terapéutica en la enfermedad crónica: estado de la situación y perspectiva de futuro. Rev Clin Esp. 2014. DOI: 10.1016/j.rce.2014.03.008

4. Pisano M, González A. La modificación de los hábitos y la adherencia terapéutica, clave para el control de la enfermedad crónica. Enferm Clin. 2014; 24 (1):59-66. DOI: 10.1016/j.enfcli.2013.10.006

5. Brown MT, Bussell J, Dutta S, Davis K, Strong S, Mathew S. Medication adherence: truth and consequences. Am J Med Sci. 2016 Apr. 351(4):387-99. DOI: 10.1016/j.amjms.2016.01.010

6. Linn AJ et al. The value of nurses' tailored communication when discussing medicines: Exploring the relationship between satisfaction, beliefs and adherence. J Health Psychol. 2014. p. 9. DOI: 10.1177/1359105314539529

7. Zullig L, Shaw R, Shah B, Peterson E, Lindquist J, Crowley M. Patient-provider communication, self-reported medication adherence, and race in a post-myocardial infarction population. Patient Prefer Adherence. 2015, 9:311-331. 10.2147/ PPA.S75393

8. Zolnierek K, Dimatteo M. Physician communication and patient adherence to treatment: a meta-analysis. Med Care. 2009; 47 (8):826-34. DOI: 10.1097\%2FMLR.0b013e31819a5acc

9. Shannon C, Weaver W. Teoría matemática de la comunicación. Madrid: Forja; 1981.

10. Corbin J, Strauss A. Basics of qualitative research. $4^{\text {th }}$ ed. Los Ángeles: Sage; 2014.

11. Strauss A, Corbin J. Bases de la investigación cualitativa. Técnicas y procedimientos para desarrollar teoría fundamentada. Medellín: Universidad de Antioquia; 2002.

12. Blumer H. Symbolic interactionism: Perspective and method. University of California Press; 1969. p. 4.

13. Valles MS. Técnicas cualitativas de investigación social. Reflexión metodológica y práctica profesional. [Internet]. Madrid: Síntesis; 1999.

14. Chiovitti R, Piran N. Rigor and grounded theory research. J adv nurs. 2003; 44(4):430. 10.1046/j.0309-2402.2003.02822.x

15. Charmaz K. Constructing grounded theory. $2^{\text {nd }}$ ed. Los Angeles: Sage; 2014.

16. Arango MC. Significados del proceso comunicativo enfermera-paciente con enfermedad coronaria para la adherencia terapéutica [Masters thesis]. [Bogotá (COL)]: Universidad Nacional de Colombia; 2018. Available in: http://bdigital.unal. edu.co/72006/1/Tesis\%20final\%20MCAR.pdf

17. Diccionario de la Lengua Española; 2017. Available in: http://dle.rae.es/?id=DgIqVCc

18. Bowlby J. Attachment and Loss (III). La pérdida afectiva. Buenos Aires: Paidós SAICF; 1983.

19. Enrique Pichon-Rivière. Vinculo y teoría de las tres D (depositante, depositario y depositado). Rol y status. The International Journal of Psychoanalysis (in Spanish), 20173 (1): 177-186. DOI: 10.1080/2057410X.2017.1490564

20. Meleis A. Theoretical nursing: development and progress. Lippincott: Williams and Wilkins; 2011.

21. Dexheimer M. Theory of health as expanding consciousness. In: Smith M, Parker M. Nursing theories and nursing practice. FA Davis, 2015, p. 279-300.

22. Noddings N. Caring: A relational approach to ethics moral education. Los Angeles, London: University of California Press; 2013. 
23. Acosta GL, Garcés A. El diálogo de saberes en comunicación o el giro del pensamiento y de la acción en las prácticas de comunicación para la movilización y el cambio social. In: Acosta GL, Pinto MC y Tapias CA (eds.), Diálogo de saberes en comunicación: colectivos y academia. Medellín; CIESPAL; 2016. p. 23-56.

24. Ramírez P, Álvarez M, Cabello D, Riquelme A, Guerra M. Vínculo terapéutico, expectativas, impacto y adherencia al tratamiento según la percepción de los usuarios del Cosam puente alto en tratamiento por adicciones. Rev GPU 2018; 14; 2: 193-201. Available in: http://www.revistagpu.cl/GPU-dic-2018.pdf\#page=101

25. Flórez I, Ruidiaz R, Hernández J. Valoración de la incertidumbre en paciente con cardiopatía isquémica. Actualizaciones en Enfermería. 2014, 17(3):15-21. Available in: https://encolombia.com/medicina/revistas-medicas/enfermeria/ ve173/valoracion-cardiopatia-isquemica/

26. Colle R. Teoría cognitiva sistémica de la comunicación: de la materia a la conciencia. Universidad Diego Portales: Santiago de Chile; 2002.

27. Peplau H. Relaciones interpersonales en enfermería. Un marco de referencia conceptual para la enfermería psicodinámica. Barcelona: Salvat; 1990.

28. King I. A theory for nursing: systems, concepts, process. Albany, Nueva York: Delmar; 1981.

29. Daley DJ, Deane KH, Gray RJ, Hill R, Myint PK. Qualitative evaluation of adherence therapy in Parkinson's disease: a multidirectional model. Patient Prefer Adherence. 2015 Jul. 10; 9:989-98. DOI: 10.2147/PPA.S80158

30. Arnow BA, Steidtmann D. Harnessing the potential of the therapeutic alliance. World Psychiatry. 2014 Oct. 13(3):23840. DOI: $10.1002 / w p s .20147$

31. Vélez AJ. Relación entre el bienestar psicológico de los psicoterapeutas y el vínculo terapéutico [Masters thesis; on line]. [Medellín]: Universidad de Antioquia; 2014.

32. Durif-Bruckert C, Roux P, Rousset H. Medication and the patient-doctor relationship: a qualitative study with patients suffering from fibromyalgia. Health Expectations. 2014, 18(6):2584-2594. DOI: 10.1111/hex.12230

33. Cófreces P, Ofman S, Stefani D. La comunicación en la relación médico-paciente. Análisis de la literatura científica entre 1990 y 2010. Revista de Comunicación y Salud, 2014 4:19-34. Available in: revistadecomunicacionysalud.org/index. $\mathrm{php} / \mathrm{rcys} / \mathrm{article} /$ download/53/72

34. Weinstein N, De Haan C. On the mutuality of human motivation and relationships. In: Netta W. Human motivation and interpersonal: theory, research, and applications. Nueva York, Londres: Springer; 2014. p. 3-24.

35. Zill JM, Christalle E, Müller E, Härter M, Dirmaier J, Scholl I. Measurement of physician-patient communication: a systematic review. 2014. PLOS ONE, 9(12). Available in: 10.1371/journal.pone.0112637 